\title{
The Similarity of the Demand Structure as a Determinant of the Commodity Structure of Bilateral Trade in the European Union Countries
}

\author{
Marek Maciejewski
}

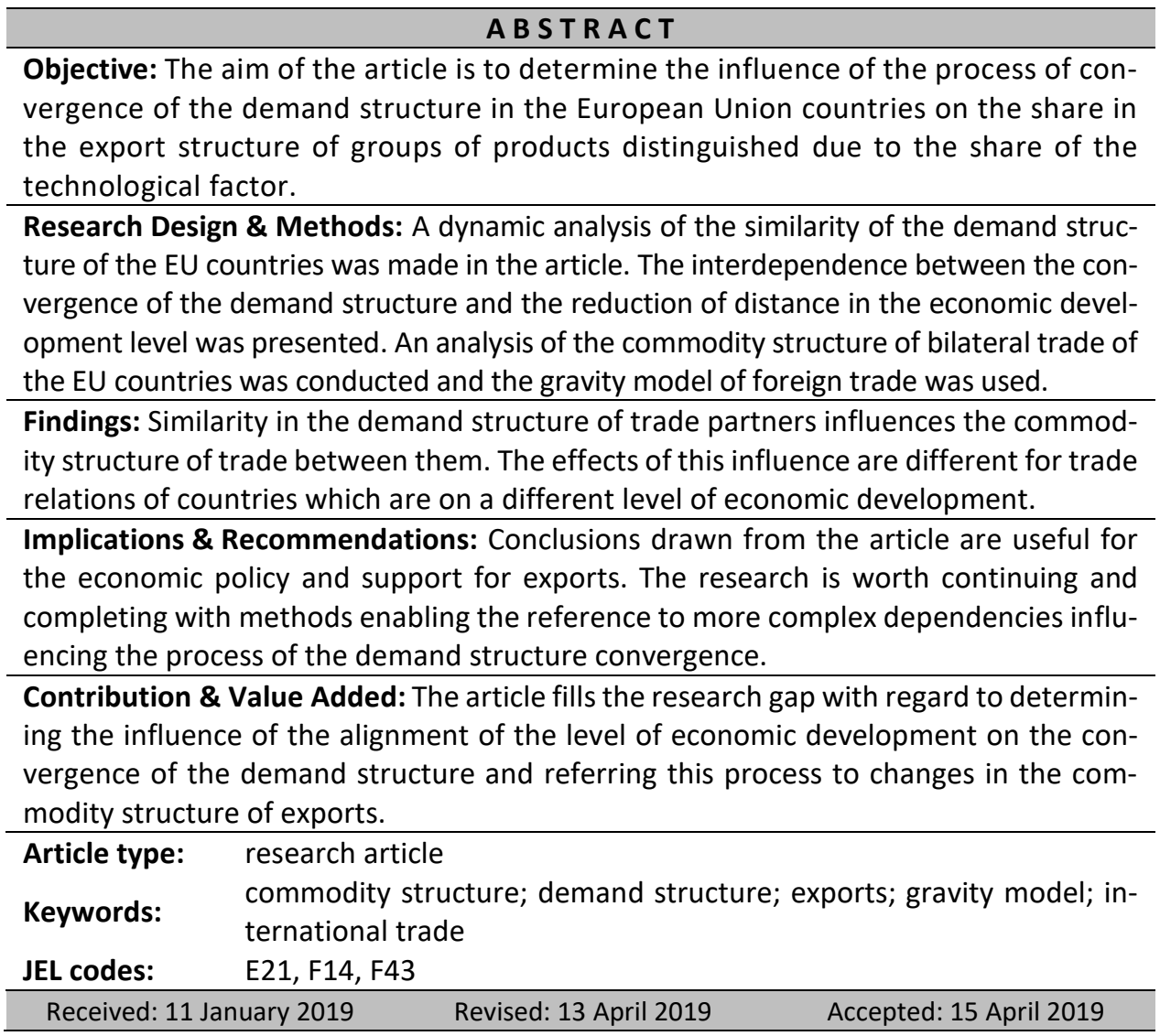

\section{Suggested citation:}

Maciejewski, M. (2019). The Similarity of the Demand Structure as a Determinant of the Commodity Structure of Bilateral Trade in the European Union Countries. Entrepreneurial Business and Economics Review, 7(2), 249-262. https://doi.org/10.15678/EBER.2019.070214 


\section{INTRODUCTION}

Among international trade theories there are those which focus on the determination of the significance of demand and supply for the exchange with abroad. The significance of differences in equipping countries with factors of production is emphasized by the Heckscher-Ohlin theory. From it we can conclude that the development of bilateral trade will take place in the first place between countries with a different level of economic development, which translates into the resources of production factors being at the disposal. On the other hand, Linder's preference similarity theory (1961) resigns from associating trade with equipping countries with factors of production, as it marginalises the supply side to the benefit of the demand approach, according to which trade cooperation will develop mainly between countries with a similar demand structure, thus, on a similar level of economic development. A country exports mainly such goods for which there is already demand on the internal market. It guarantees undertaking profitable production and conducting effective competition with producers of identical or similar goods on foreign markets. It allows to increase the production scale based on the experience gained so far.

In spite of the fact that Heckscher-Ohlin theory and Linder's theory were created several dozen years ago, authors still write new papers (Lai et al., 2016; Görkemli et al., 2018) which attempt to diagnose the export development path, opposing these theories. In numerous works Linder's theory is empirically tested (McPherson et al., 2001; Dhakal et al., 2011; Viciu et al., 2016), referring it, however, only to the difference in the level of GDP per capita and skipping the issues of the difference in the trade commodity structure. I decided to fill this research gap, completing the deliberations with a real analysis of the process of convergence of the demand structure. The aim of the article is to determine the impact of this process on the share in the export structure of groups of products distinguished for the share of the technological factor. And here we can put forward the hypothesis that greater sensitivity to the distance between trade partners will be characteristic for goods with a low share of technology.

In the research part I focused in the first place on the analysis of the demand structure of the European Union countries. Then I conducted a dynamic comparative analysis of the demand structures of each pair of those countries. I distinguished in it the EU member states before the enlargement in 2004 (EU15) and new member states (EU10, as I excluded Croatia, Cyprus, Malta from the analysis, due to lack of data or their incompleteness). In the first part I conducted an analysis of the correlation between the convergence process of the demand structure and shortening the distance in the economic development level of the countries, measured with GDP per capita. Then, using the gravity model of foreign trade, I analysed the influence of selected factors, with special consideration to the convergence process of the demand structure, on the commodity structure of exports of the EU states in their bilateral trade.

\section{LITERATURE REVIEW}

The empirical verification of Linder's theory, observed in the literature of the subject, does not bring explicit conclusions. Its confirmation based on the analysis of the impact of differences in the value of GDP per capita on streams of trade can be found already in the 
works by Sailors et al. (1973), Thursby and Thursby (1987), but also in more recent publications which include works by such authors as Fink et al. (2005) or Faustino and Leitão (2006) with regard to Portuguese industry products, and Çağlayan-Akay and Oskonbaeva (2018) for trade of selected OECD countries. Some of the studies (Chow et al., 1999) indicate limitations of the verifiability of the theory to entities on a higher level of economic development. For example, Hanink (1988) observed that a high level of trade between similar but poor countries is unlikely. The theory was not confirmed in the results obtained for individual countries of East Africa (McPherson et al., 2001), or in research findings for East Asia countries (Dhakal et al., 2011) or Romania (Viciu et al., 2016).

It seems that the role of territorial distance when conducting cross-border activity is quite important. It is a factor which may disturb or weaken the trend of export growth arising from similarity of the demand structure. Although Cairncross (2001) observes that at present geographical distance is not important in the era of global markets, Ellis (2007)emphasizes the fact that empirical evidence indicates that distance still matters, also in hi-tech goods trade. A lot of research points to a negative relationship of trade and distance (Batra, 2006; Ravishankar \& Stack, 2014; Maciejewski, 2017). The research by Linnemann (1966), as well as Frankel et al. (1997) emphasize major costs affecting trade, namely physical shipment cost, cost related to time and cost of the ignorance of culture (Lai et al., 2016).

\section{MATERIAL AND METHODS}

According to Linder's theory (1961), the alignment of the level of GDP per capita of countries leads to the standardisation of their demand structure. To determine the demand structure of the European Union countries I initially adopted three methods based on:

- global demand structure (GDP_demand),

- the structure of demand for products according to their durability level (Durable_demand),

- the structure of consumption expenses according to COICOP (COICOP_demand).

In the analysis of the global demand structure (GDP_demand) I used a four-element system including the demand of the state, private consumption demand, private investment demand and net exports (Malmberg \& Power, 2005). In the literature there is an emphasis on the significance of the impact of changes in the level of economic development on shifts in the global demand structure between its elements (Cavallo, 2005; Włodarczyk, 2015). It is related to transformations in the production structure, the growth of the importance of the services sector and the use of modern technologies.

In the structure of demand for products according to their durability level (Durable_demand) there are also four elements distinguished: durable goods, semi-durable goods, non-durable goods and services. In the demand structure there is a shift towards durable goods in response to rising incomes (Lee, 1964; Conrad \& Schroeder, 1991). Possessing durable goods is regarded the indicator of the economic development level of a country (Beerli, 2010).

The most extended demand structure is included in the classification of consumption expenses according to COICOP (COICOP_demand). The Classification of Individual Consumption by Purpose (COICOP) was developed by the United Nations Statistical Division for the classification and analysis of individual consumption expenses incurred 
by households and non-commercial institutions acting for households and governmental and self-governmental institutions (UN, 2018). On the level of a two-digit code of divisions, COICOP groups the areas of expenses of households for consumption goods and services: food and non-alcoholic beverages (01), alcoholic beverages and tobacco (02), clothing and footwear (03), housing and energy carriers (04), furnishings, household equipment and routine household maintenance (05), health (06), transport (07), information and communication (08), recreation and culture (09), education (10), restaurants and hotels (11) other goods and services (12). In the demand structure of countries on a lower level of economic development, expenses for food and non-alcoholic beverages prevail. It is confirmed by the data for new European Union member states, where at the beginning of the analysed period, in 2000 , this category of products absorbed over $20 \%$ of expenses in the case of seven of them (even more than $30 \%$ in Romania and Lithuania). On the other hand, among EU15 countries, the highest $16 \%$ share of this group of products was marked only by the poorest of them - Greece and Portugal. Economic growth, bringing a higher level of manageable income should lead to appropriate shifts in the consumption expenses structure. In 2017 only in four European Union countries food expenses constituted $20 \%$ of total consumption expenses, not exceeding the level of $30 \%$ (EUROSTAT, 2019).

Based on the methodology described by Wydymus (1988), I conducted a dynamic comparative analysis of the demand structures of the European Union countries, for the three aforementioned ways of determining the demand structure. In all those cases, for each $i$-th object (the European Union country, $i=1, \ldots, k$ ) I analysed the structure described with the series $m(j=1, \ldots, m)$ of indicators of the share of the elements of structure $q$ in total demand $\left(q=q_{1}, \ldots, q_{m}\right)$ in individual years $t$ of the analysed period $(t=1, \ldots, n)$. Due to the fact that for each method there is the following formula adopted:

$$
q_{j t}^{i}=\frac{x_{j t}^{i}}{\sum_{j=1}^{m} x_{j t}^{i}}
$$

the following conditions are fulfilled:

$$
q_{j t}^{i} \in[0 ; 1]
$$

and

where:

$$
\sum_{j=1}^{m} x_{j t}^{i}=1
$$

$x_{j t}^{i}$ - expressed in Euro value of $j$-th element in the demand structure of the $i$-th country in year $t$;

$q_{j t}^{i}$ - share of $j$-th element in the demand structure of $i$-th country in year $t$;

$i$ - European Union countries $(i=1, \ldots, k)$;

$j$ - demand structure elements $(j=1, \ldots, m)$, where depending on the adopted method: $m=4$ for GDP_demand and Durable_demand or $m=12$ for COICOP_demand;

$t$ - individual years $(t=1, \ldots, n)$, where:

$n$ - number of analysed years in the period 2000-2017.

Data obtained from the Eurostat base (2019) allowed to construct for individual countries, for each of the three methods, a three-dimensional matrix of information, composed of the series of sub-matrices in the following form: 


$$
Q^{i} \Rightarrow\left\{\left[Q_{j t}^{1}\right],\left[Q_{j t}^{2}\right], \ldots,\left[Q_{j t}^{k}\right]\right\}
$$

Each of the matrices of the above series has the form of:

$$
Q^{i}=\left[\begin{array}{c}
Q_{1 t}^{i} \\
\vdots \\
Q_{j t}^{i}
\end{array}\right]=\left[\begin{array}{ccc}
q_{11}^{i} & \cdots & q_{1 n}^{i} \\
\vdots & \vdots & \vdots \\
q_{m 1}^{i} & \cdots & q_{m n}^{i}
\end{array}\right]
$$

In the comparative analysis of the demand structures, the basis of the research are individual, treated separately, matrices $Q^{i}$, forming the series (4). I conducted a study of the similarity of the demand structures for each pair of the European Union countries in individual years of the period. As, due to incomplete data, I excluded Croatia, Cyprus and Malta from the analysis, I obtained 300 pairs of countries ${ }^{1}$, which gives 5,400 observations for 18 years included in the analysis.

As the measure of the demand structures dissimilarity for each pair of countries $i$ and I in year $t$ I adopted Euclidian distance, given in the formula (McCune \& Grace, 2002):

$$
d_{i l}^{t}=\sqrt{\sum_{j=1}^{m}\left(q_{j t}^{i}-q_{j t}^{l}\right)^{2}}
$$

The value of measure (6) is the closer to zero, the more similar the discussed demand structures of two countries are, and with the rise in the dissimilarity structures level its values are higher and higher. I presented a fragment of the obtained results which indicate changes in the similarity of the demand structure in one of the analysed pairs of countries - in Poland and Germany - in Figure 1.

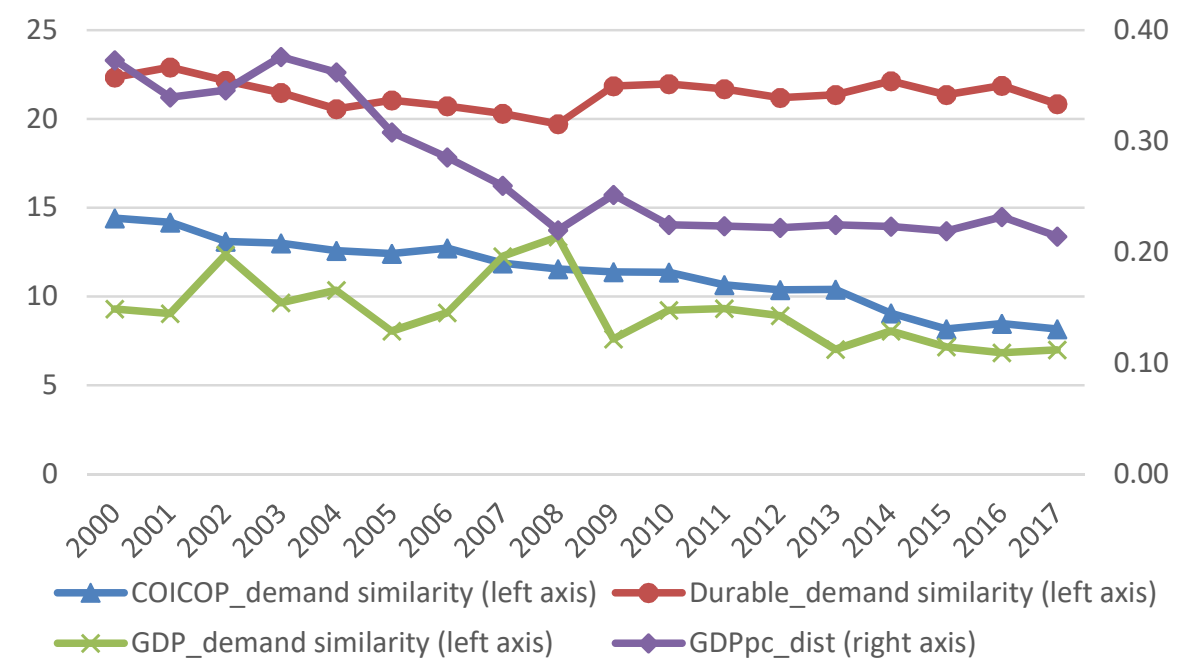

Figure 1. Similarity of the demand structure and the distance of GDP per capita between Poland and Germany in the years 2000-2017 Source: own calculations based on the data of EUROSTAT (2019).

\footnotetext{
${ }^{1}$ At this stage I eliminated the differentiation in the arrangement Reporter_A-Partner_B and Reporter_B-Partner_A., but it will be important in the further part of the analysis devoted to the export structure, which will cause doubling of the number of observations.
} 
What results from Chart 1 is that the highest level of dissimilarity in the demand structures in Poland and Germany refers to the structure basing on the demand for products according to their durability level. On a lower level, with a declining trend, dissimilarity forms in the global demand structure and the structure of consumption expenses according to COICOP. I obtained similar comparisons, which I am not able to place here, for all pairs of the European Union countries.

As it was mentioned before, Linder's theory indicates close relationship between the alignment of the economic development level of countries, whose measure is GDP per capita, and the convergence of the demand structure. I decided to leave in the further analysis in the area of interest, only this form of the presentation of the demand structure whose changes in similarity are correlated to the highest extent with changes in the distance in the GDP level per capita of the analysed pairs of countries.

For this purpose I calculated the indicator of a relative difference in the level of GDP per capita of entities $i$ and I belonging to the analysed pairs of countries (GDPpc_dist ${ }_{i l}$ ) in individual years by means of the formula (Somma, 1994):

$$
G D P p c_{-} d i s t_{i l}^{t}=1+\frac{(w) \ln (w)+(1-w) \ln (1-w)}{\ln (2)}
$$

where:

$$
w=\frac{G D P p c_{i}^{t}}{G D P p c_{i}^{t}+G D P p c_{l}^{t}}
$$

whereas:

$G D P p c_{i}^{t} ; G D P p c_{l}^{t}$ - mean, respectively, GDP per capita in country $\mathrm{i}$ and I in year $\mathrm{t}$.

The indicator is a normalised measure adopting values from the range $[0,1]$, where zero means identical GDP per capita of countries, and approximation to one is equal to the growth of the difference between their GDP per capita.

In Figure 1 the broken line stands for a change in the distance in GDP per capita between Poland and Germany in the period 2000-2017. Its run shows the gradual reduction of this distance and the highest convergence of this process with the convergence of consumption expenses structure according to COICOP (a correlation coefficient between these variables in the period $2000-2017$ was 0.821 ). The convergence is high also with regard to the other pairs of the European Union countries. Table 1 presents a correlation coefficient between changes in the distance of GDP per capita and changes in the level of similarity of the demand structure for the European Union countries and the groups of countries distinguished from them (EU10 and EU15).

The analysis of the data from Table 1 allows to prove positive correlation between reduction of the distance of GDP per capita and the process of convergence of the demand structures for pairs of countries in all the analysed groups of the European Union countries. This correlation the strongest when changes in the demand structure are represented by shifts in consumption expenses classified according to COICOP. Only within mutual relations of countries from the EU15 group transformations in the global demand structure were more significant. Changes in the distance of GDP per capita and convergences in the demand structures within EU 10 countries, characterised by a lower, similar within the group, level of economic development, were the most poorly correlated. It lets us think that they are oriented to the consumption level of more highly developed countries. 
Table 1. Correlation coefficient between changes in the distance of GDP per capita and similarity of the demand structure for the group of the European Union countries in the years 2000-2017

\begin{tabular}{|c|c|c|c|c|c|c|}
\hline \multicolumn{2}{|c|}{ Group of countries } & \multicolumn{3}{|c|}{ Number of } & \multicolumn{2}{c|}{ Correlation coefficient: GDPpc_dist and } \\
\hline Reporter & Partner & $\begin{array}{c}\text { Countries } \\
\text { pairs }\end{array}$ & Observations & $\begin{array}{c}\text { COICOP_- } \\
\text { Demand } \\
\text { similarity }\end{array}$ & $\begin{array}{c}\text { Durable_ } \\
\text { Demand } \\
\text { similarity }\end{array}$ & $\begin{array}{c}\text { GDP_ } \\
\text { demand } \\
\text { similarity }\end{array}$ \\
\hline EU10 & EU10 & 45 & 810 & 0.4127 & 0.0762 & 0.3615 \\
\hline EU10 & EU15 & 150 & 2700 & 0.6226 & 0.1181 & 0.5622 \\
\hline EU10 & EU28 & 195 & 3510 & 0.6463 & 0.3276 & 0.5674 \\
\hline EU15 & EU15 & 105 & 1890 & 0.5134 & 0.1973 & 0.7624 \\
\hline EU15 & EU28 & 255 & 4590 & 0.6959 & 0.5039 & 0.3972 \\
\hline EU28 & EU28 & 300 & 5400 & 0.6801 & 0.5053 & 0.4361 \\
\hline
\end{tabular}

Source: own calculations based on the data of EUROSTAT (2019).

In the light of the above, I decided to relate the analysis of bilateral trade of the European Union countries to changes in the structure of their demand expressed in the level of consumption expenses classified according to COICOP.

In order to do this, I used the gravity model of foreign trade, whose idea referring to Newton's gravitation law assumes that the value of trade exchange between two countries is proportional to the product of income of those countries, thus, to their masses, and inversely proportional to the distance between them, which translated into the costs of transport, diminishing the attractiveness of trade exchange (Tinbergen, 1962). The concept has become a popular instrument of trade modelling, mainly due to the possibility to develop a formula with new variables for the needs of testing their impact on trade streams (Maciejewski \& Wach, 2019). In the group of model variables explaining bilateral trade of the European Union countries I decided to include the measure of similarity of their demand structure based on consumption expenses classified according to COICOP (COICOP demand similarity, COICOP_DS il). In the group of the remaining explanatory variables I included the basic data of the gravity model:

- GDP of exporter $\left(G D P_{i}\right)$ and GDP of its trade partner $\left(G D P_{l}\right)$ based on UNCTAD data (2019),

- distance in kilometres between trade partners' capital cities (Distil) based on CEPII base (2019)

and

- distance between the value of GDP of the exporter and its trade partner (GDP_distil), calculated in accordance with formulas (7) and (8),

- value of GDP per capita of the country of exporter $\left(G D P p c_{i}\right)$ and its trade partner (GDPpcl) based on UNCTAD data (2019),

- dummy variable which indicates the possession of a common border by a pair of countries (Borderil).

The dependent variable in the model is the share in the structure of the exports of products classified based on their technological advancement on the basis of the methodology proposed by Lall (2000). In this approach, we distinguish in the export structure: 
- primary products (PP) with scarce technological advancement,

- resource based products $(\mathrm{RB})$ primarily using local abundance of natural resources,

- low technology products (LT) mainly using technologies included in capital equipment,

- medium technology products (MT), which use technologies with moderate engagement of R\&D,

- high technology products (HT) using advanced and fast changing technologies, and those requiring investment in $R \& D$.

Therefore, I estimated parameters of five models for the share in the exports share $\left(E X_{i l}\right)$ of individual categories of products $j(j=1, \ldots m)$. Models of bilateral trade of countries $i, l$, take on the following form:

$$
\begin{gathered}
E x_{i l j}^{t}=\alpha_{0}+\alpha_{1} \text { COICOP_DS }_{i l j}^{t}+\alpha_{2} G D P_{i j}^{t}+\alpha_{3} G D P_{l j}^{t}+\alpha_{3} D i s t_{i l j}^{t}+ \\
\alpha_{3} \text { Border }_{i l j}^{t}+\alpha_{4} G D P_{-} \text {dist }_{i l j}^{t}+\alpha_{5} G D P p c_{i j}^{t}+\alpha_{6} G D P_{l j}^{t}+\varepsilon_{i l j}^{t}
\end{gathered}
$$

In order to consider the specific character of trade between partner in sa similar and on different levels of economic development, I estimated four time in the ReporterPartner arrangement:

- EU10-EU10 - exports of EU10 countries to the market of the remaining countries of this group (90 pairs of countries, 1,620 observations in the period of the analysed 18 years),

- EU10-EU15 - exports of EU10 countries to the market of EU15 countries (150 pairs of countries, 2,700 observations),

- EU15-EU10 - exports of EU15 countries to the market of the remaining countries of this group (150 pairs of countries, 2,700 observations)

- EU15-EU15 - exports of EU15 countries to the market of the remaining countries of this group (210 pairs of countries, 3,780 observations).

\section{RESULTS AND DISCUSSION}

I estimated the values of the models' parameters with the panel regression method in Gretl software. Wald test and Breusch-Pagan test (Zaman, 2000) excluded the possibility of correct deduction based on the classical least squares method (pooled OLS), and in all the cases Hausman test indicated the superiority of fixed effects estimator (FE) over the random effects estimator (RE). However, FE estimator, due to collinearity, does not allow to use the variables whose values are fixed in time for each pair of countries. In the conducted analysis it concerned the variables which are crucial for gravity models, such as geographical distance and the common border. In those cases I applied two-level regression (Chenga \& Walla, 2005), on the second stage making the regression of those variables on the absolute term which were obtained on the first stage, including the remaining data (I presented the results obtained in this way in the summary below in italics). I conducted the diagnosis of the models with regard to the normality of the distribution of residuals and heteroscedasticity based on Doornik-Hansen and Wald test.

In Table 2 I present the results of the estimation for the whole model only for trade within EU15 countries, and in Table 3 I presented the results obtained from all the models, but only with reference to variable COICOP_DS $i$, as the parameter estimated for this variable is the main area of interest in this article. 
The analysis of the results included in Table 2 shows that individual elements of the commodity structure of exports in trade between EU15 countries in react differently to changes in explanatory variables adopted for the analysis. For example, possessing a common border (Borderil) promotes an increase in the share in the export structure of basic goods (PP), resource based ones (RB) and low technology products (LT) at the expense of more technologically advanced products (MT and HT), whose share in the export structure declines. It indicates limitations in the entry to distant markets for low technology goods which are sold mainly in the nearest geographical environment. And the distance expressed in the distance between countries' capital cities is less important - in this case the value of the parameter is close to zero, and the variable for low and medium technology goods is statistically insignificant. Distance measured with the size of economies is more important (GDP_distil). The bigger it is, the smaller the shares of low and medium technology goods in exports are. However, it does not concern technologically most advanced goods, which means that those products are least sensitive to the distance between the sizes of economies.

Table 2. Estimation of model parameters using the FE estimator for exports of EU15 group countries to EU15 group countries

\begin{tabular}{|c|c|c|c|c|c|}
\hline Variable & PP & RB & LT & MT & HT \\
\hline Const & $\begin{array}{c}11.542^{* * *} \\
(0.953)\end{array}$ & $\begin{array}{c}21.063^{* * *} \\
(1.687)\end{array}$ & $\begin{array}{c}22.484 * * * \\
(1.365)\end{array}$ & $\begin{array}{c}27.685^{* * *} \\
(1.552)\end{array}$ & $\begin{array}{c}17.226^{* * *} \\
(2.191)\end{array}$ \\
\hline COICOP_DS & $\begin{array}{c}-0.316 * * * \\
(0.056)\end{array}$ & $\begin{array}{c}-0.834 * * * \\
(0.099)\end{array}$ & $\begin{array}{c}0.188^{* *} \\
(0.080)\end{array}$ & $\begin{array}{c}0.613 * * * \\
(0.091)\end{array}$ & $\begin{array}{c}0.349 * * * \\
(0.128)\end{array}$ \\
\hline$G D P_{i}$ & $\begin{array}{c}0.000 \\
(0.000) \\
\end{array}$ & $\begin{array}{c}0.000 * * * \\
(0.000)\end{array}$ & $\begin{array}{c}0.000 * * * \\
(0.000)\end{array}$ & $\begin{array}{c}-0.000^{* * *} \\
(0.000) \\
\end{array}$ & $\begin{array}{c}-0.000 \\
(0.000)\end{array}$ \\
\hline$G D P_{l}$ & $\begin{array}{c}0.000 \\
(0.000)\end{array}$ & $\begin{array}{c}0.000 \\
(0.000)\end{array}$ & $\begin{array}{c}-0.000 * * * \\
(0.000)\end{array}$ & $\begin{array}{c}-0.000 \\
(0.000)\end{array}$ & $\begin{array}{c}0.000 * * * \\
(0.000)\end{array}$ \\
\hline Dist $_{i l}$ & $\begin{array}{c}-0.000 * * * \\
(0.000)\end{array}$ & $\begin{array}{c}0.000^{* * *} \\
(0.000)\end{array}$ & $\begin{array}{c}0.000 \\
(0.000) \\
\end{array}$ & $\begin{array}{l}-0.000 \\
(0.000) \\
\end{array}$ & $\begin{array}{c}-0.000 * * * \\
(0.000)\end{array}$ \\
\hline Border $_{i l}$ & $\begin{array}{c}1.679 * * * \\
(0.398)\end{array}$ & $\begin{array}{c}4.506^{* * *} \\
(0.537)\end{array}$ & $\begin{array}{c}3.519 * * * \\
(0.519)\end{array}$ & $\begin{array}{c}-2.250^{* * *} \\
(0.581)\end{array}$ & $\begin{array}{c}-7.557^{* * *} \\
(0.606)\end{array}$ \\
\hline$G D P_{-} d_{i s t_{i l}}$ & $\begin{array}{l}-3.818^{*} \\
(2.064)\end{array}$ & $\begin{array}{c}18.681 * * * \\
(3.654)\end{array}$ & $\begin{array}{c}-13.475 * * * \\
(2.957)\end{array}$ & $\begin{array}{c}-15.206 * * * \\
(3.361)\end{array}$ & $\begin{array}{c}13.818^{* * *} \\
(4.747)\end{array}$ \\
\hline$G D P p c_{i}$ & $\begin{array}{l}-0.000 \\
(0.000)\end{array}$ & $\begin{array}{l}0.000^{*} \\
(0.000)\end{array}$ & $\begin{array}{c}0.000 \\
(0.000)\end{array}$ & $\begin{array}{c}0.000 * * \\
(0.000)\end{array}$ & $\begin{array}{c}-0.000^{* * *} \\
(0.000)\end{array}$ \\
\hline$G D P p c_{l}$ & $\begin{array}{c}0.000 * * * \\
(0.000)\end{array}$ & $\begin{array}{l}-0.000 \\
(0.000)\end{array}$ & $\begin{array}{c}-0.000 * * * \\
(0.000)\end{array}$ & $\begin{array}{c}0.000 * * * \\
(0.000)\end{array}$ & $\begin{array}{c}-0.000 * * * \\
(0.000)\end{array}$ \\
\hline LSDV R-squared & 0.846 & 0.756 & 0.821 & 0.843 & 0.672 \\
\hline Within R-squared & 0.061 & 0.055 & 0.028 & 0.055 & 0.054 \\
\hline
\end{tabular}

Note: PP - Primary products, RB - Resource based products, LT - Low technology products, MT - Medium technology products, HT - High technology products. Estimated standard errors appear in parentheses. *** $\mathrm{p}<0.01 ; * * \mathrm{p}<0.05 ; * \mathrm{p}<0.10$.

Source: own calculations based on the data of UNCTAD (2019) and EUROSTAT (2019).

With regard to the analysis of the influence of the convergence of the demands structures (COICOP_DS $\left.S_{i l}\right)$ on the share of individual categories of goods in the export structure, unambiguous responses for all groups of countries concern the basic products (PP) only. Their share in the export structure grows with a decline in the dissimilarity of the demand 
structure of trade partners. It means that those products reveal high sensitivity to differences in buyers' preferences. We can conclude that in this case the market entry strategy consists in the use of the position on the domestic market and copying locally proven solutions based on specific consumption patterns, which is possible only when they are characterised by a high level of similarity. Opposite conclusions may be drawn due to the results obtained for the exports of products of medium (MT), low (LT) and - to the smallest extent - high (HT) technology. The share of those products in the export structure was growing with an increase in the dissimilarity of the demand structure of trade partners, which points to lower sensitivity of those product categories to differences in the demand structure, thus, their greater universality. However, it is worth emphasizing that with regard to HT products, it concerns only trade within the EU15 countries group and for LT products it does not concern trade within the group of EU10 countries. It proves a different impact of the convergence of the demand structure on the commodity structure of trade for countries at a different level of economic development.

Table 3. Estimation of COICOP_DS variable using the FE estimator for EU countries exports

\begin{tabular}{|c|c|c|c|c|c|}
\hline Variable & PP & RB & LT & MT & HT \\
\hline \multirow{2}{*}{ EU10-EU10 } & $-10.289^{*}$ & 6.497 & $-14.509^{*}$ & $29.204^{* * *}$ & -10.902 \\
& $(5.681)$ & $(9.582)$ & $(8.102)$ & $(10.426)$ & $(10.247)$ \\
\hline \multirow{2}{*}{ EU10-EU15 } & $-0.570^{* * *}$ & $0.375^{* * *}$ & $0.662^{* * *}$ & 0.101 & $-0.568^{* * *}$ \\
& $(0.092)$ & $(0.129)$ & $(0.135)$ & $(0.158)$ & $(0.139)$ \\
\hline \multirow{2}{*}{ EU15-EU10 } & -0.089 & $-0.314^{* * *}$ & $0.291^{* * *}$ & $0.408^{* * *}$ & $-0.296^{* * *}$ \\
& $(0.061)$ & $(0.101)$ & $(0.085)$ & $(0.119)$ & $(0.110)$ \\
\hline \multirow{2}{*}{ EU15-EU15 } & $-0.316^{* * *}$ & $-0.834^{* * *}$ & $0.188^{* *}$ & $0.613^{* * *}$ & $0.349^{* * *}$ \\
& $(0.056)$ & $(0.099)$ & $(0.080)$ & $(0.091)$ & $(0.128)$ \\
\hline
\end{tabular}

Note: PP - Primary products, RB - Resource based products, LT - Low technology products, MT - Medium technology products, HT - High technology products. Estimated standard errors appear in parentheses. $* * *$ $\mathrm{p}<0.01 ; * * \mathrm{p}<0.05 ; * \mathrm{p}<0.10$.

Source: own calculations based on the data of UNCTAD (2019) and EUROSTAT (2019).

\section{CONCLUSIONS}

The conducted analysis proves that the similarity of the demand structure of trade partners affects the commodity structure of the trade between them. It turns out, however, that the effects of this influence are different for trade relations of countries on a different level of economic development. It concerns particularly technologically advanced products. Although the convergence of the demand structure favours the growth of share in the export structure of all the EU countries, as for the trade with goods using technology, particularly HT products, it concerns mainly EU new member states. For the EU countries at a higher level of economic development the distance of the demand structure is not that significant in the exports of technologically advanced products. On the contrary, their share in the commodity structure of exports grows at the expense of basic products, the supply of which is burdened with costs related to geographical distance. Linder's theory corresponds with the traditional stages theory of internationalisation, which suggests that firms internationalise only after a period of domestic maturing. Therefore, in the first phase they operate only on the internal market, and only with growing experience they 
gradually enter foreign markets. The most known stages model is regarded to be the Uppsala model by Johanson and Vahlne (1977), assuming the stepwise internationalisation process, starting from the lack of regular exports activity, through exports with the use of intermediaries, trade affiliates, and ending with manufacturing affiliates characterised by the highest level of engagement on foreign markets. In the stages approach, the internationalisation of firms is perceived as an effect of the learning process, with which the engagement of resources on foreign markets is growing (Wach, 2014). However, we can assume that such an internationalisation model is adopted mainly in traditional industries. Firms operating in high tech industries usually skip individual stages of internationalisation, they undertake activity on international markets from inception or soon after their establishment (Daszkiewicz, 2019). Their offer is more universal and less prone to an influence of the differences in the demand structure.

The conducted analysis is based only on macro-economic data, which is a limitation, as decisions about undertaking trade exchange in a specific industry and geographical direction are taken on the firm's level. However, the problem is worth further research to be conducted. A method which should be used in it is the structural modelling method SEM, which allows to draw conclusions with reference to more complex dependencies, which would enable to consider a number of other factors in addition to GDP per capita, affecting the process of the demand structure convergence.

\section{REFERENCES}

Batra, A. (2006). India's global trade potential: The gravity model approach. Global Economic Review, 35(3), 327-361.

Beerli, A. (2010). The Evolution of Durable Goods Demand During China's Transition. Institute for Empirical Research in Economics University of Zurich Working Paper, 494, 1-68.

Çağlayan-Akay, E., \& Oskonbaeva, Z. (2018). Empirical Analysis of the Linder Hypothesis: A RandomEffects Tobit Model. The Empirical Economics Letters, 17(1), 87-97.

Cairncross, F. (2001). The death of distance: How the communications revolution is changing our lives. Boston: Harvard Business School Press.

Cavallo, M. (2005). Government Consumption Expenditures and the Current Account. FRB of San Francisco Working Paper, (2005)03, 1-26.

CEPII. (2019). CEPII database. Retrieved from http://www.cepii.fr/cepii/en/bdd_modele/bdd.asp. on April 20, 2019.

Cheng, I.H., \& Wall, H.J. (2005). Controlling for Heterogeneity in Gravity Models of Trade and Integration. Federal Reserve Bank of St. Louis Review, 87(1), 49-63.

Chow, P., Kellman, M., \& Shachmurove, Y. (1999). A Test of the LinderHypothesis in Pacific NIC Trade 1965-1990. Applied Economics, 31(2), 175-182.

Conrad, K., \& Schroder, M. (1991). Demand for Durable and Nondurable Goods, Environmental Policy and Consumer Welfare. Journal of Applied Econometrics, 6(3), 271-286.

Daszkiewicz, N. (Ed.) (2019). Internationalization of High-Tech Firms: Patterns, Innovation and Research and Development. Cambridge: Cambridge Scholars Publishing.

Dhakal, D., Pradhan, G., \& Upadhyaya, K.P. (2011). Another Empirical Look at the Theory of Overlapping Demands. International Economics, 64(1), 103-113. 
Ellis, P.D. (2007). Paths to foreign markets: Does distance to market affect firm internationalisation?. International Business Review, 16(5), 573-593.

EUROSTAT (2019). Eurostat Database. Retrieved from https://ec.europa.eu/eurostat/data/database on April 20, 2019.

Fink, C., Javorcik, B.S., \& Spatareanu, M. (2005). Income-Related Biases in International Trade: What do Trademark Registration Data Tell Us?. Review of World Economics, 141(1), 79-103.

Görkemli, K., Altuğ, K., \& Tamer, S. (2018). Bilateral Trade in European Sports Industry: Linder versus Hecksher-Ohlin-Samuelson. International Journal of Economics and Financial Issues, 8(1), 48-53.

Hanink, D.M. (1988). An extended Linder model of international trade. Economic Geography, 64(4), 322-334.

Johanson, J., \& Vahlne, J.-E. (1977). The Internationalization Process of the Firms - A Model of Knowledge Development and Increasing Foreign Market Commitments. Journal of International Business Studies, 8(1), 23-32.

Lai, A.A., Lai, M.F., \& Bujang, I. (2016). The Heckscher-Ohlin versus Linder's Theory: evidence from Malaysian exports. Journal of Business and Retail Management Research, 10(2), 85-93.

Lall, S. (2000). The Technological Structure and Performance of Developing Country Manufactured Exports, 1985-98. Oxford Development Studies, 28(3), 337-369.

Lee, M.A. (1964). Income, Income Change, and Durable Goods Demand. Journal of the American Statistical Association, 59(308), 1194-1202.

Faustino, H., \& Leitão, N.C. (2007). Country-Specific Determinants of Intra-Industry Trade in Portugal. Working Papers Department of Economics, (2007)/27, 1-23.

Frankel, J.A., Stein, E., \& Wei, S.J. (1997). Regional trading blocs in the world economic system. Washington: Institute for International Economics.

Linder, S.B. (1961). An Essay on Trade and Transformation. Uppsala: Almqvist \& Wiksells Boktryckeri AB.

Linnemann, H. (1966). An econometric study of international trade flows. Amsterdam: North-Holland Publishing Company.

Maciejewski, M. (2017). Determinanty wykorzystania czynników wytwórczych w strukturze eksportu państw Unii Europejskiej. Horyzonty Polityki, 8(22), 131-149.

Maciejewski, M., \& Wach, K. (2019). What determines export structure in the EU countries? The use of gravity model in international trade based on the panel data for the years 1995-2015. Journal of International Studies, 12(1), 151-167. https://doi.org/10.14254/2071-8330. 2019/12-1/10

Malmberg, A., \& Power, D. (2005). On the role of global demand in local innovation processes. In G. Fuchs \& Ph. Shapira (Eds.), Rethinking regional innovation and change, (pp. 273-290). New York: Springer.

McCune, B., \& Grace, J.B. (2002). Analysis of Ecological Communities. Gleneden Beach, Oregon: MjM Software Design.

McPherson, M.A., Redfearn, M.R., \& Tieslau, M.A. (2001). International trade and developing countries: an empirical investigation of the Linder hypothesis. Applied Economics, 33(5), 649-657.

Ravishankar, G., \& Stack, M.M. (2014). The Gravity Model and Trade Efficiency: A Stochastic Frontier Analysis of Eastern European Countries' Potential Trade. The World Economy, 37(5), 690-704.

Sailors, J., Qureshi, U., \& Cross, E. (1973). An Empirical Verification of Linder's Trade Thesis. Southern Economic Journal, 40(2), 262-268.

Somma, E. (1994). Intra-industry trade in the European computers industry. Weltwirtschaftliches Archiv, 130(4), 784-799.

Thursby, J., \& Thursby, M., (1987). Bilateral Trade Flows, the Linder Hypothesis, and Exchange Risk. The Review of Economics and Statistics, 69(3), 488-495. 
Tinbergen, J. (1962). Shaping the World Economy; Suggestions for an International Economic Policy. New York: Twentieth Century Fund. Retrieved from http://hdl.handle.net/1765/16826, on May 10, 2019.

UN. (2018). Classification of Individual Consumption According to Purpose (COICOP) 2018. Statistical Paper, 99. New York: United Nations.

UNCTAD. (2019). UNCTADStat. Retrieved from https://unctadstat.unctad.org on April 10, 2019.

Viciu, T.G., Mihoreanu, L., \& Costea, C. (2016). An Essay on the Applicability of the Linder Hypothesis in Determining the Patterns of the Romanian International Trade. Journal of Economic Development, Environment and People, 5(1), 52-62.

Wach, K. (2014). The Role of Knowledge in the Internationalisation Process: An Empirical Investigation among Polish Businesses (chapter 7). In D. Kiendl-Wendner \& K. Wach (Eds), International Competitiveness in Visegrad Countries: Macro and Micro Perspectives, (pp. 143-158). Graz: Fachhochschule Joanneum.

Włodarczyk, R.W. (2015). Struktura popytu globalnego a wzrost gospodarczy w krajach Europy Środkowej i Wschodniej. Optimum. Studia Ekonomiczne, 3(75), 3-19.

Wydymus, S. (1988). Analiza porównawcza struktur gospodarczych. In A. Zeliaś (Ed.), Metody statystyki międzynarodowej, (pp. 162-199). Warszawa: Państwowe Wydawnictwo Ekonomiczne.

Zaman, A. (2000). The Inconsistency of the Breusch-Pagan Test. Journal of Economic and Social Research, 2(1), 1-11. 


\section{Author}

\section{Marek Maciejewski}

Assistant Professor in the Department of International Trade, PhD in economics, author of publications on international trade, scientific secretary of the journal 'International Entrepreneurship'. He was the chairman and member of the organizing committees of many national and international conferences. He is a member of international scientific societies, including Academy of International Business (AIB) and European International Business Academy (EIBA).

Correspondence to: Dr Marek Maciejewski, Cracow University of Economics, ul. Rakowicka 27, 31-510 Kraków, Poland, e-mail: maciejem@uek.krakow.pl

ORCID (1) http://orcid.org/0000-0003-1343-3764

\section{Acknowledgements and Financial Disclosure}

This article is financed from the funds allocated to the Faculty of Economics and International Relations of the Cracow University of Economics in the framework of grants for maintaining research potential.

The author would like to thank the anonymous referees for their useful comments, which allowed to increase the value of this article.

\section{Copyright and License}

This article is published under the terms of the Creative Commons Attribution - NoDerivs (CC BY-ND 4.0) License http://creativecommons.org/licenses/by-nd/4.0/

Published by the Centre for Strategic and International Entrepreneurship - Krakow, Poland 